\title{
The External Cost of Electricity Generation: An Applicable Approach for Environmental Decision-Making on Electricity Exportation Strategy
}

\author{
Saeed Ghoddousi ${ }^{1}$, Ahmad Farhad Talebi ${ }^{1^{*}}$
}

${ }^{1}$ Faculty of New Sciences and Technologies, Semnan University, Semnan, IRAN

*Corresponding Author: aftalebi@semnan.ac.ir

Citation: Ghoddousi, S. and Talebi, A. F. (2021). The External Cost of Electricity Generation: An Applicable Approach for Environmental Decision-Making on Electricity Exportation Strategy. European Journal of Sustainable Development Research, 5(3), em0165. https://doi.org/10.21601/ejosdr/11077

\section{ARTICLE INFO}

Received: 22 Sep. 2019

Accepted: 7 May 2021

\begin{abstract}
The Burning of fossil fuels, such as coal, fuel oil, natural gas, and diesel in power sector, has become one of the major sources of air pollutants, namely $\mathrm{CO}_{x}, \mathrm{NO}_{\mathrm{x}}$ and $\mathrm{SO}_{\mathrm{x}}$. These are thought to adversely affect the environment and human health. This paper assesses the external cost of electricity production from fossil fuel power plants in Iran using the Extern-E study. In addition, the future of average amount of emissions and their external cost was predicted according to the development of Iran's power generation system. Investigation of power generation planning in Iran from 2013 to 2023 shows that the average emissions of $\mathrm{PM}_{10}, \mathrm{SO}_{2}$, CO, and $\mathrm{CO}_{2}$ will reduce by $26.7 \%, 54.2 \%, 65.4 \%$, and $20 \%$, respectively, in fossil power plants. Moreover, it was predicted that the average external cost of power generation in 2023 would decrease up to $28.9 \%, 27.6 \%$, and $23.1 \%$ in low, medium, and high scenarios, respectively. Moreover, analyzing the trend of Iran's electricity exportation and considering the prospect of Iran's energy sector, we claim that substitution of old gas power plants with high throughput combined cycle will help achieve the goal of Iran's power generation development more sustainably.
\end{abstract}

Keywords: Iran's power generation sector, external cost of emissions, fossil fuel power plants, electricity export

\section{INTRODUCTION}

World gross electricity production by an average annual growth rate of $3.4 \%$ has almost triplicated during 1974 and 2015, reaches to around 28000 terawatt hour (TWh) in 2019. While $68.5 \%$ of the energy utilized worldwide originates from fossil fuels (i.e., coal, natural gas, and oil), in non-OECD countries, $73.9 \%$ of the electricity production originates from fossil fuel (Electricity Information 2017, 2017).

The use of fossil fuels for electricity production negatively impacts the environment compared with renewable energy sources (i.e., solar, wind, and geothermal). The combustion of fossil fuels in thermal power plants produces pollutants such as greenhouse gases (GHGs), $\mathrm{SO}_{\mathrm{x}}, \mathrm{NO}_{\mathrm{x}}$, and soot (Bergerson and Lave, 2004), which causes critical environmental issues such as particulate matter (PM), ground-level ozone, acid rain, and global warming (Nazari et al., 2010).

Iran has one of the largest gas and oil reservoirs in the world (Bilgin, 2009). Iran is bordered by 13 countries in the region, and its 83 million populations in 2019 have spread over an area of 1,648,195 square kilometers (Aghahosseini et al., 2018). The electricity sector is heavily subsidized by the government (Sabetghadam, 2006). Iran's electricity production was around $280 \mathrm{TWh}$ in 2015 . The annual average growth rate of power generation reached $7.7 \%$ from 1978 to 2015 (Electricity Information 2019, 2019). During this time scale, Iran's power industry has experienced a rapid expansion of power plants due to its growing domestic needs, intensified industrialization, and electricity export ambition (Iran's Power Industry Analysis Investment Risks \& Opportunities in PostSanctions Era, 2015).

Emissions from fossil fuel power plants is considered a potential polluting agent that largely threatens the human health and the environment, which could be further considered as a phenomenon with external cost (Alavijeh et al., 2013). An external cost describes whenever a social or economic activity of one group impacts another group. The subject would be more complicated when that impact is not fully accounted for or compensated for (Bickel and Friendrich, 2004). The external costs are quantifiable based on health and environmental damages (Chatzimouratidis and Pilavachi, 2009). The ExternE methodology provides a framework for transforming external impacts of energy expressed in different units into a common unit, a nominal monetary unit (Bickel and 
Friendrich, 2004). The ExternE method and data are used in different external cost studies in various countries.

The environmental external cost from the power generation system was investigated using the ExternE method in seventeen Middle Eastern countries. Results showed that $64 \%$ of the total external cost was caused by power plants that used fuel oil. At the same time, these power plants represented $32 \%$ of the entire power generation. Also, it was shown that using renewable energies instead of fossil fuel reduced $15-20 \%$ of external costs during nine years (El-Guindy and Mahmoud, 2014). The assessment of health impacts and external costs of a natural gas power plant in Iran was also performed using the ExternE method (Fouladi Fard et al., 2016). The annual external cost of emission for selected gas power plant with 714 MW generation capacity was approximately 4.76 million US\$. The study revealed that $\mathrm{NO}_{\mathrm{x}}$ has the most share of emissions and the highest amount of external costs compared with $\mathrm{PM}_{10}$, $\mathrm{CO}$, and $\mathrm{SO}_{2}$ in the gas power plant.

The external cost analysis for 21 European countries was done using the ExternE method. The study investigated the impact of trading electricity on the external cost of power generation. Those countries that relied on electricity imports were outsourcing the grid's stability to other countries and induced environmental damage beyond their borders. Also, the study indicated that the lowest external costs of electricity were for Norway, Sweden, and Switzerland due to the high ratio of nuclear or renewable energy in their electricity generation system (Weinzettel, Havránek and Ščasný, 2012). The external cost of gaseous and particulate matter emissions from the thermal power plants in India was calculated based on the similar methodology (Srinivasan and Shekhar, 2020). It was revealed that total external cost in 2030 will be about two times greater than 2020. This study illuminates the role of emission in final power generation cost and shows that power generation from fossil fuel sources is not always the cheapest generation method. Štreimikienè (2020) disscused the role of renewable energy in power systems using the ExternE method in four European countries. The external cost assessment from 2010 to 2018 indicated that due to penetration of renewable sources of energy, the average external cost of power generation reduced significantly in Poland and Hungary. In contrast, the average external costs of power generation were almost stable in the Czech Republic and Slovakia during the same period. This study showed that by enhancing governmental support from renewable sources, the total external cost of power generation could decrease (Štreimikienè, 2020).

Finding a sustainable, clean, and costly effective energy trading model is a critical need in the global energy market. Although environmental damage is an inevitable output of an energy system that depends on fossil fuel sources, the impact of this damage on the countries' electricity trading plan has not been considered seriously. The aim of the present is to quantify the environmental damage through a power generation system that highly depends on fossil fuels and investigates its impact on the electricity exportation plan. Quantifying environmental damage has been performed with energy external cost approach. Also, the external cost calculation belonged to the exported electricity from Iran to neighborhood countries is considered. Besides, the estimation of the future of fossil fuel consumption and emissions in Iran's power generation system and the effect of keeping the current trend for the next years is performed. The results will clarify the real amount of government's benefit from generating and exporting electricity to the neighborhood countries.

\section{MATERIAL \& METHOD}

\section{Power Generation Emissions}

The nominal capacity of power plants, type of electricity generation, the volume of air pollutants emissions $\left(\mathrm{CO}_{2}, \mathrm{NO}_{\mathrm{x}}\right.$, $\mathrm{SO}_{2}, \mathrm{CO}$, and $\mathrm{PM}_{10}$ ), and the amount of import and export of electricity generated are obtained from Iran's energy balance 2015 (Iran Energy Balance, 2015, 2017). It is clear that real power production, types of consumed fuels and the amount of burned fuels determine the final volume and type of pollutants emitted by a power plant.

An electricity supply system is organized into three parts: production, transmission, and distribution. In this system, power plants which are located all over the country generate electricity power. The transmission and distribution system provide electricity for final consumers. Hence, the exported electricity power could be generated in different locations spread out across the country. Calculations of external cost of electricity export in this paper are done based on average annual emissions from each type of power plant.

\section{External Cost of Emissions}

Based on the energy supply and demand, environmental energy review in Iran (EER) assessed environmental damage from air pollution in Iran using the ExternE study that has extended over 10 years (Bank, 2004), and its findings were used to calculate external costs in the present study. Damage costs were transferred from Western European practice to the conditions of Iran by scaling according to gross domestic product (GDP) per capita measured in purchasing power parity (PPP) terms (Shafie-Pour and Ardestani, 2007). The official exchange rate GDP per capita in Iran was about $15 \%$ of the EU, and by using estimation of PPP exchange rate in the United Nations Development Program, GDP per capita in Iran on a PPP basis in 2002 was calculated to be $25.3 \%$ of the average of industrialized countries; consequently, the values for damage costs in Iran was calculated $25.3 \%$ of those derived for the EU (Bank, 2004). Therefore, an average damage cost is adopted and applied to all sources.

To calculate the external costs of a fossil fuel power plant, modeling of the distribution of pollutions from power plants to different receptors, such as humans, animals, plants, and materials is crucial. The final receptors might be located thousands of kilometers away. Since air pollutants can damage a number of receptors, the task of analyzing the impacts of any given emission is fairly complex, and it is a gross simplification to assume a certain amount of costs for each tone of pollutant which is emitted from the power plant. Moreover, transferring this value of damage cost from EU countries to another country with different weather, climate, population density and economic preferences may cause some errors in calculations. Considering these issues and paying attention to limited access to some geographical data and emissions from each 
power plant in Iran, EER project results in three different scenarios (low, medium, high estimation about damage cost of emissions). These scenarios were employed to achieve a reasonable calculation of the emission external cost which is exported from Iran's electricity supply system (Shafie-Pour and Ardestani, 2007). The methods of calculation of the external cost of pollutants were as follows (Wijaya and Limmeechokchai, 2010):

\section{External cost of $\mathrm{CO}_{2}$}

Human expansion of the "greenhouse effect" and non-stop growing emission of its main cause, carbon dioxide, largely comes from the power sector. $\mathrm{CO}_{2}$ emitted from burning of fossil fuels accounts for $\sim 80 \%$ of the Earth's annual emission to the atmosphere (Overview of Greenhouse Gases," Environmental Protection... - Google Scholar, 2016). The external cost of produced $\mathrm{CO}_{2}$ in power sector in Iran was calculated according to the Eq. (1):

$$
\begin{gathered}
\mathrm{CO}_{2} \text { Damage cost }(\$)=\mathrm{CO}_{2} \text { emissions }\left(\mathrm{g} \mathrm{CO}_{2} / \mathrm{kWh}\right) \\
\times 10^{-6}\left(\text { ton } \mathrm{CO}_{2} / \mathrm{g} \mathrm{CO}_{2}\right) \times \text { Unit damage cost }(\$ / \text { ton } \\
\left.\mathrm{CO}_{2}\right) \times \text { electricity generation }(\mathrm{kWh})
\end{gathered}
$$

\section{External cost of $\mathrm{SO}_{2}$}

$\mathrm{SO}_{\mathrm{x}}$ are a group of corrosive gases mostly emitted from burning of sulfur-containing fuels, particularly coal and oil, which are heavily burned in thermal power plants to generate power. Once sulfur releases into the atmosphere, it combines with atmospheric oxygen to form different type of sulfur oxides such as $\mathrm{SO}_{2}$ and $\mathrm{SO}_{3}$ (Int, 2019). They react with atmospheric water to form sulfurous acid and sulfuric acid, responsible for an environmental hazard called acid precipitation. The external cost of this pollutant is calculated according to Eq (2).

$$
\begin{gathered}
\mathrm{SO}_{2} \text { Damage cost }(\$)=\mathrm{SO}_{2} \text { emissions }\left(\mathrm{g} \mathrm{SO}_{2} / \mathrm{kWh}\right) \times \\
10^{-6}\left(\text { ton } \mathrm{SO}_{2} / \mathrm{g} \mathrm{SO}_{2}\right) \times \text { Unit damage cost }\left(\$ / \text { ton } \mathrm{SO}_{2}\right) \\
\times \text { electricity generation }(\mathrm{kWh})
\end{gathered}
$$

\section{External cost of $\mathrm{NO}_{X}$}

Similar to $\mathrm{SO}_{x}$, different combinations of $\mathrm{N}_{2}$ and $\mathrm{O}_{2}$ are the output of combustion process. $\mathrm{NO}_{2}$ is a powerful GHG produced by a verity of industrial activities, especially cultivation practices and fossil fuel combustion. $\mathrm{NO}_{2}$ is harmful to the skin, irritates respiratory systems, and may increase asthmatic patients' symptoms (Chauhan et al., 2003). $\mathrm{NO}_{2}$ could react with atmospheric humidity to form nitric acid $\left(\mathrm{HNO}_{3}\right)$. The resultant acid precipitation negatively affects human and plant health as well as corrosion of metal surfaces due to the corrosive substance. Eq. (3) is used to calculate the external cost of $\mathrm{NO}_{\mathrm{x}}$.

$$
\begin{gathered}
\mathrm{NO}_{\mathrm{x}} \text { Damage cost }(\$)=\mathrm{NO}_{\mathrm{x}} \text { emissions }\left(\mathrm{g} \mathrm{NO}_{\mathrm{x}} / \mathrm{kWh}\right) \\
\times 10^{-6}\left(\text { ton } \mathrm{NO}_{\mathrm{x}} / \mathrm{g} \mathrm{NO}_{\mathrm{x}}\right) \times \text { Unit damage cost }(\$ / \text { ton } \\
\left.\mathrm{NO}_{\mathrm{x}}\right) \times \text { electricity generation }(\mathrm{kWh})
\end{gathered}
$$

\section{External cost of PM10}

Smoke, soot, dust, ash, pollen and many other tiny particles, dispersed in the atmosphere are known as particle matter (PM) or aerosol. They are emitted from different natural and industrial activities. PMs are introduced as dominant air pollution form because they reduce visibility and leave deposits of dirt on the surfaces. Coarse particles with a diameter between 2.5 and 10 micrometers $\left(\mathrm{PM}_{10}\right)$ not only can settle in the bronchi and lungs but also can cause climate change by impacting the net amount of incoming and outgoing solar wave radiation (Yin, Pizzol and $\mathrm{Xu}, 2017$ ). Considering the negative effects of $\mathrm{PM}$, the external cost of $\mathrm{PM}_{10}$ released by activities of power sector was calculated using Eq. (4).

$$
\begin{aligned}
& \mathrm{PM}_{10} \text { Damage cost }(\$)=\mathrm{PM}_{10} \text { emissions }\left(\mathrm{g} \mathrm{PM}_{10} /\right. \\
& \mathrm{kWh}) \times 10^{-6}\left(\text { ton } \mathrm{PM}_{10} / \mathrm{gP}_{10}\right) \times \text { Unit damage cost }
\end{aligned}
$$

$\left(\$ /\right.$ ton $\left.\mathrm{PM}_{10}\right) \times$ electricity generation $(\mathrm{kWh})$

\section{External cost of $\mathrm{CO}$}

Carbon monoxide (CO) is a colorless, odorless, and tasteless gas. $\mathrm{CO}$ is mostly produced during incomplete combustion of fossil fuels. CO contributes to a serious health problem: it displaces oxygen in the blood and deprives the heart, brain and other vital organs of oxygen. The most common symptoms of $\mathrm{CO}$ poisoning are headaches, dizziness and nausea in higher concentrations (Widdop, 2002). In order to calculate the external coast of $\mathrm{CO}$ coming from power sector, Eq. (5) was used.

$$
\begin{gathered}
\text { CO Damage cost }(\$)=\text { CO emissions }(\mathrm{g} \mathrm{CO} / \mathrm{kWh}) \times \\
10^{-6}(\text { ton CO } / \mathrm{g} \mathrm{CO}) \times \text { Unit damage cost }(\$ / \text { ton CO }) \times \\
\text { electricity generation }(\mathrm{kWh})
\end{gathered}
$$

\section{RESULT \& DISCUSSION}

\section{Iran Power Supply System}

The nominal capacity of Iran's power generation system in 2015 was 74,184.4 MW (Electric Power Industry in Iran (20152016), 2015). Iran's power generation system includes nine types of power plants steam power plants (15829.2 MW), gas turbines (26870 MW), combined-cycle plants (18493.1 MW), hydroelectric plants (11353.9 MW), nuclear (1020 MW), diesel power plants (439.4 MW), wind (158 MW), biogas (11.6 MW) and solar (9.2 MW). It could be noted that nuclear, wind, biogas and solar power plants use renewable source of energy. The accumulative electricity generation by such green power plants composes only $5.1 \%$ of total electricity generation in Iran (Iran Energy Balance, 2015, 2017). Although hydro-power plants could potentially generate $15.3 \%$ of total nominal capacity of Iran's electricity, this record has dropped to 5\% in recent years due to the water shortage throughout the country (Mazandarani et al., 2011). The share of each type of power plants in nominal capacity and electricity generation in 2015 is shown in Figure 1.

As shown in Figure 1, fossil fuel power plants are the dominant type of electricity producers in Iran and they generated around 94\% of total electricity generation in 2015 . The type of fuel consumed in those power plants plays a major role in determining their emissions. Fuel oil, diesel, and natural gas are three types of fossil fuels usually burn in Iran's power plants. Figure 2 shows the amount of fossil fuel consumption in these power plants from 2008 to 2015. 


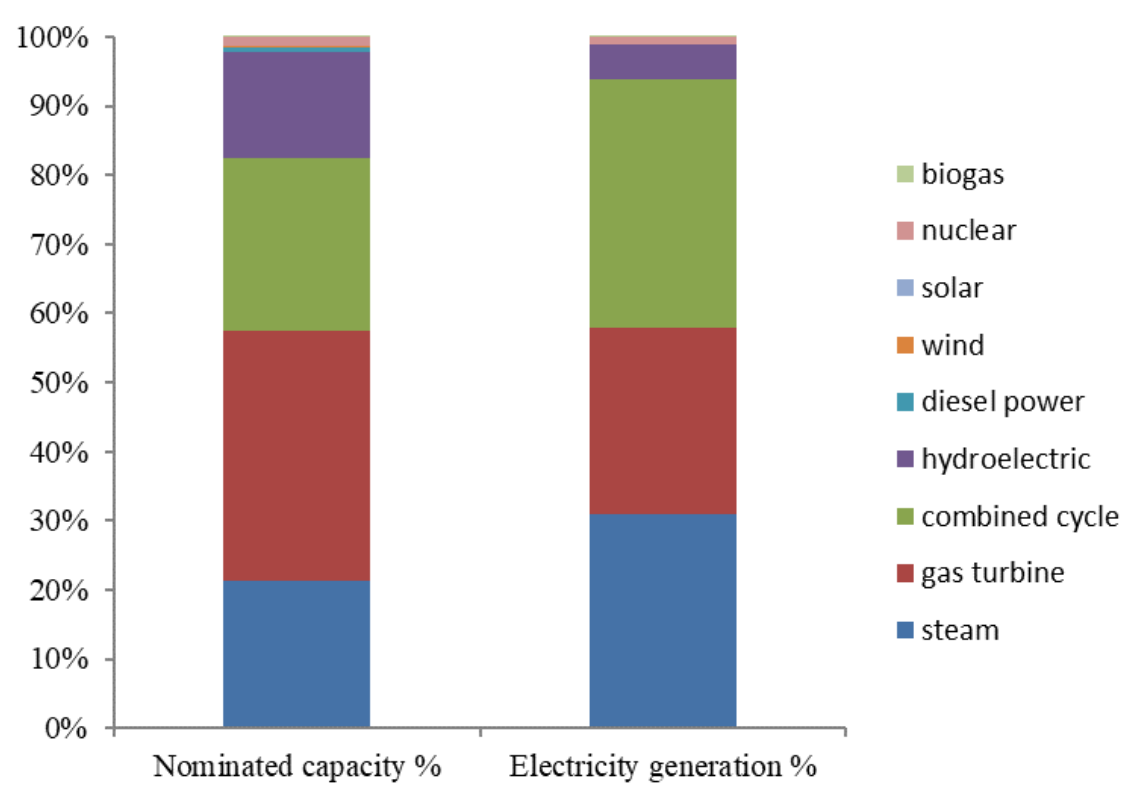

Figure 1. Nominal capacity and electricity generation of each type of power plant in 2015 in Iran

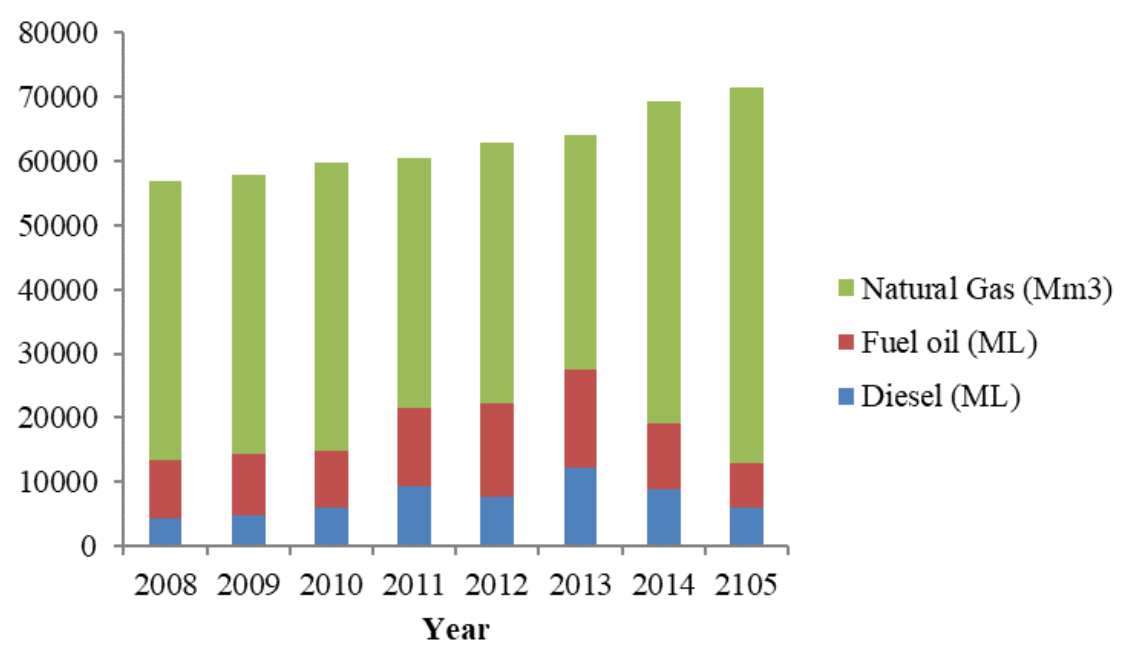

Figure 2. Trend of fossil fuel consumption in Iran's fossil fuel power plants

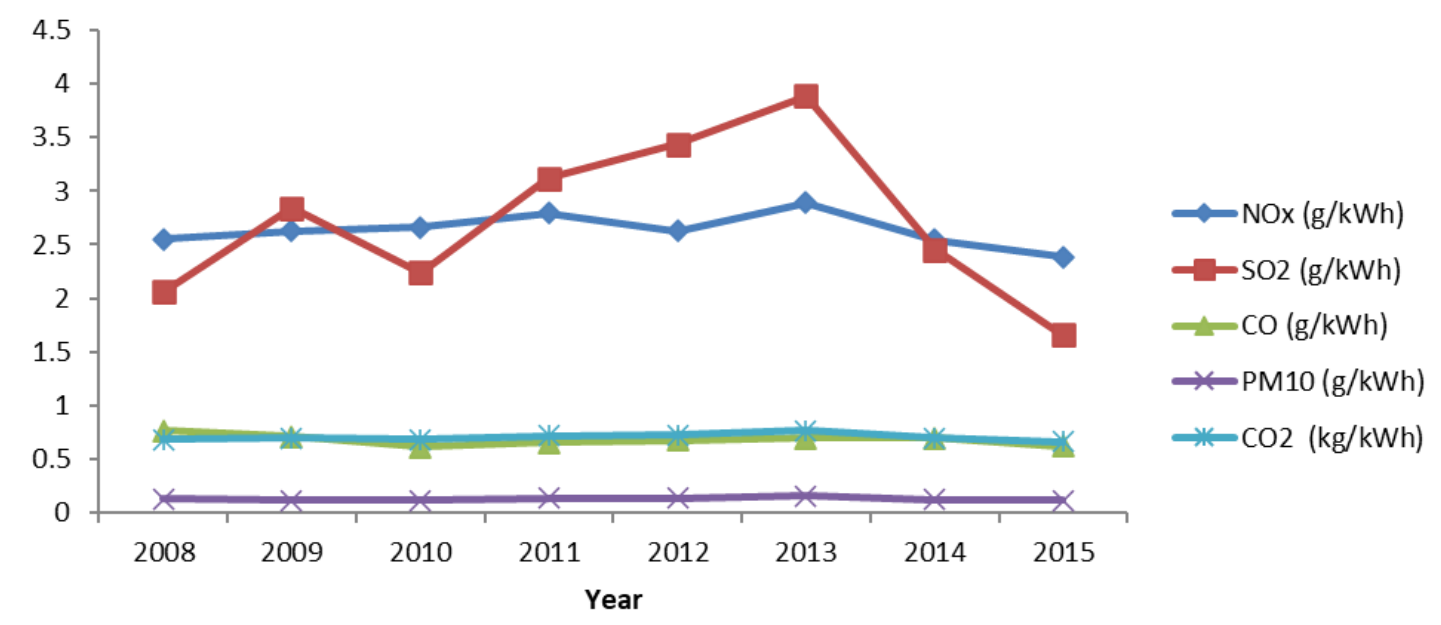

Figure 3. Trend of the average pollutions production from power plants in Iran

According to Figure 2, total fuel consumption continuously increased during this time. Moreover, natural gas was the dominant fuel burned in fossil power plants.
Fuel oil and diesel as a heavier commercial fraction of crude oil release more air pollutions in comparison with natural gas. Figure 3 indicates the trend of the average pollution 
Table 1. EU damage cost and their transferred to Iran condition

\begin{tabular}{cccc}
\hline Pollutant & EU damage cost (\$/ton) & Source & Transfer cost to Iran situations (\$/ton) \\
\hline $\mathrm{PM}_{10}$ & 17200 & (Bickel and Friendrich, 2004) & 4300 \\
\hline $\mathrm{NOx}$ & 2400 & (Bickel and Friendrich, 2004) & 1825 \\
\hline $\mathrm{SO}_{2}$ & 7300 & (Bickel and Friendrich, 2004) & 600 \\
\hline $\mathrm{CO}$ & 750 & (Bickel and Friendrich, 2004) & 188 \\
\hline
\end{tabular}

Table 2. The damage cost of pollutions by transferring EU data to Iran's condition (Bank, 2004)

\begin{tabular}{cccc}
\hline Pollutant & Low(\$/ton) & Medium (\$/ton) & High(\$/ton) \\
\hline $\mathrm{PM}_{10}$ & 2150 & 4300 & 8600 \\
\hline $\mathrm{SO}_{2}$ & 912 & 1825 & 3650 \\
\hline $\mathrm{NO}_{\mathrm{x}}$ & 300 & 600 & 1200 \\
\hline $\mathrm{CO}$ & 94 & 188 & 376 \\
\hline $\mathrm{CO}_{2}$ & 3 & 10 & 80 \\
\hline
\end{tabular}

production from power generation plants in Iran from 2008 to 2015. Figure 3 illuminates that Iran' energy policy decisionmakers try to reduce the use of heavy fraction of crude oil burned in thermal power plants, since the less combustion of fuel oil, the less emission of air pollutants there would be. Considering Figure 3, the average emission of $\mathrm{SO}_{2}$ and $\mathrm{NO}_{x}$, has fallen $57.3 \%$ and $17.6 \%$ since 2013 . One of the critical factors in making this change is reduction of heavy fossil fuel consumption like diesel and fuel oil from 12186.3 ML and 15263.5 ML to 6083.3 ML and 6945.8 ML, respectively (Iran Energy Balance, 2015, 2017).

Since natural gas is a cleaner fuel than other fossil fuels, it is considered as the main energy source in fossil power plants in Iran. However, due to an increase in natural gas consumption in household sector in the colder months of the year, the natural gas network cannot supply all demands. Hence, thermal power plants have to use secondary fuels such as fuel oil or diesel (Iran Energy Balance, 2015, 2017), leading to increased emissions from power plants in a colder season.

Depending on the type of power plant and fuel that gets consumed in the plants, the amount and type of pollutants are different. Burning heavier fuels such as heavy oil and diesel leads to the release of more massive pollutants such as $\mathrm{SO}_{\mathrm{x}}$ and PM (Mazandarani et al., 2011).

\section{Environmental Damage Cost of Emission of Iranian Thermal Power Plants}

EER calculates total environmental damage from air pollution in Iran using the ExternE on the basis of the energy supply and demand. In the EER, just four kinds of pollutants $\left(\mathrm{PM}_{10}, \mathrm{SO}_{2}, \mathrm{NO}_{\mathrm{x}}\right.$ and $\mathrm{CO}$ ) were investigated (Bank, 2004). These pollutants impose the most of damage cost from the energy sector on health and environment. They are responsible for effects on human health $\left(\mathrm{PM}_{10}, \mathrm{SO}_{2}, \mathrm{NO}_{\mathrm{x}}\right.$ and $\left.\mathrm{CO}\right)$, ecological damages $\left(\mathrm{SO}_{2}\right.$ and $\left.\mathrm{NO}_{\mathrm{x}}\right)$, and climate change $(\mathrm{CO})$ in the local and regional scale (Gwilliam et al., 2003). By applying the ExternE method and its data from the EU region, the damages caused by the pollutants were transformed to the monetary unit in Table 1. The transfer damage cost for Iran situation (EER) is also shown (in 2001 US dollar).

EER project estimated the damage cost of pollution by transferring the damage value of ExternE project in EU to Iran condition by using GDP exchange rate (GDP per capita in Iran on a PPP basis in 2002 was calculated $25.3 \%$ of the average of industrialized countries), which is shown in Table 1 . Due to some of the uncertainties in transferring estimated damage value, the determined cost can have various amounts ranging from $50 \%$ to $200 \%$ of the mean calculated cost (Bank, 2004; Shafie-Pour and Ardestani, 2007). As a result, three different scenarios were considered low, medium, and high, which were $50 \%, 100 \%$, and $200 \%$ of transferring values from EU countries, respectively. Although there is a substantial degree of uncertainty regarding the exact damage costs, the errors will tend to be consistent over time; therefore, time trends will be unaffected (Bank, 2004).

Three amounts of damage cost values were determined for emitted $\mathrm{CO}_{2}$ :

1. Low: The prototype carbon fund (PCF) has conducted a number of trades with typical values of $\$ 3 / t \mathrm{CO}_{2}$ equivalent. They represent the disadvantage that may occur in Iran by the world trading system to control its carbon production (Kelly and Jordan, 2004).

2. Medium: Estimates have been made of prices in a world trading scheme. It was based on anticipated values in the future EU carbon trading scheme (Shafie-Pour and Ardestani, 2007).

3. High: Intergovernmental panel on climate change (IPCC) has estimated the damage costs of $\mathrm{CO}_{2}$. The value of $\$ 80 / \mathrm{t} \quad \mathrm{CO}_{2}$ corresponds by chance to the value of $\mathrm{CO}_{2}$ abatement implied by the renewable order certificate (ROC) (Metz et al., 2005).

The damage cost of the major air pollutants $\mathrm{PM}_{10}, \mathrm{SO}_{2}, \mathrm{NO}_{x}$ and $\mathrm{CO}$, which are emitted from fossil fuel power plants, are summarized in Table 3. By exploiting ExternE's results in the EU and transferring them to Iran's condition, the damage cost of $\mathrm{PM}_{10}, \mathrm{SO}_{2}, \mathrm{NO}_{\mathrm{x}}$ and $\mathrm{CO}$ were estimated. Besides, the damage value for $\mathrm{CO}_{2}$ was directly estimated (Bank, 2004). The calculations were performed based on three scenarios (low, medium, high external cost).

The average pollutants emission produced by Iran's power sector in 2013-2015 is summarized in Table 3. Moreover, the external costs of emissions are calculated using the average of emissions released by three types of power plants based on three different scenarios.

Generally, $\mathrm{SO}_{2}$ and $\mathrm{CO}_{2}$ are two dominant gas pollutants emitted by power plants per generated electricity, regardless of the power plant type. To be more specific, steam power plants have a higher potential to produce more $\mathrm{PM}_{10}, \mathrm{SO}_{2}$, and $\mathrm{CO}$ than gas and combined cycle power plants. As previously 
Table 3. The external cost of electricity generation of Iran 2013- 2015 in three scenarios

\begin{tabular}{|c|c|c|c|c|c|c|c|c|c|c|c|}
\hline \multirow{2}{*}{ Year } & \multirow{2}{*}{$\begin{array}{c}\text { Type of } \\
\text { power } \\
\text { plant } \\
\end{array}$} & \multirow{2}{*}{$\begin{array}{c}\text { Power plants } \\
\text { nominal capacity } \\
\text { (MW) }\end{array}$} & \multirow{2}{*}{$\begin{array}{c}\text { Power } \\
\text { generation } \\
(\text { GWh })\end{array}$} & \multicolumn{5}{|c|}{ Average emission (g/kWh) } & \multicolumn{3}{|c|}{ External cost scenarios (Cents/kWh) } \\
\hline & & & & $\mathbf{P M}_{10}$ & $\mathrm{SO}_{2}$ & $\mathrm{NO}_{\mathrm{x}}$ & $\mathrm{CO}$ & $\mathrm{CO}_{2}$ & Low & Medium & High \\
\hline \multirow{4}{*}{2013} & Steam & 15829.2 & 87105.5 & 0.2 & 9.3 & 2.4 & 1.7 & 894.0 & 1.24 & 2.85 & 11.06 \\
\hline & Gas & 24715 & 62048.2 & 0.2 & 1.1 & 2.8 & 0.1 & 822.9 & 0.46 & 1.25 & 7.45 \\
\hline & C.Cycle & 17850 & 87135.1 & 0.1 & 0.4 & 3.2 & 0.1 & 500.6 & 0.31 & 0.81 & 4.63 \\
\hline & Ave. & & & 0.2 & 3.9 & 2.8 & 0.7 & 730.2 & 0.69 & 1.68 & 7.74 \\
\hline \multirow{4}{*}{2014} & Steam & 15829.2 & 83165.9 & 0.2 & 6.6 & 2.2 & 2.0 & 808.2 & 0.96 & 2.25 & 9.35 \\
\hline & Gas & 26412 & 69527.8 & 0.1 & 0.7 & 2.3 & 0.1 & 814.3 & 0.41 & 1.14 & 7.17 \\
\hline & C.Cycle & 18493.1 & 96823 & 0.1 & 0.3 & 3.0 & 0.1 & 480.6 & 0.28 & 0.75 & 4.39 \\
\hline & Ave. & & & 0.1 & 2.5 & 2.6 & 0.7 & 682.8 & 0.54 & 1.36 & 6.82 \\
\hline \multirow{4}{*}{2015} & Steam & 15829.2 & 84582.4 & 0.2 & 4.5 & 2.2 & 1.8 & 745.2 & 0.76 & 1.81 & 10.64 \\
\hline & Gas & 26870 & 71369.4 & 0.1 & 0.5 & 1.8 & 0.1 & 790.5 & 0.36 & 1.04 & 6.82 \\
\hline & C.Cycle & 18493.1 & 100935.6 & 0.1 & 0.2 & 2.9 & 0.1 & 470.0 & 0.26 & 0.71 & 4.25 \\
\hline & Ave. & & & 0.1 & 1.7 & 2.4 & 0.6 & 649.7 & 0.45 & 1.16 & 6.23 \\
\hline
\end{tabular}

mentioned, steam power plants can consume varied fuel types in their boilers, especially heavy oil fuel, and potentially release more air pollutants. On the other hand, higher amounts of two harmful GHGs., $\mathrm{CO}_{2}$ and $\mathrm{NO}_{\mathrm{x}}$ were emitted from gas and combined cycle power plants, respectively. Hence, the external cost of electricity generation would have different values since types of fuel combusted in different power plants determine the emitted pollutions.

Table 3 shows three scenarios (low, medium, and high) for all three types of thermal power plants (steam, gas, and combined cycle) are employed to produce a whole picture of the last available power sector status in Iran. Since the emission of $\mathrm{PM}_{10}, \mathrm{SO}_{2}$, and $\mathrm{CO}$ from steam power plants was considerably higher than two other types of power plants, the estimated external cost for this type of power plant is higher. Accordingly, Iran's energy policy is to increase the contribution of gas and combined power plants, and they try to decrease the generation of steam power plants in Iran's power supply system. As a result, the amount of generated power from gas and combined cycle power plants grew 15\% and $15.8 \%$, respectively, between 2013 to 2015 . On the other hand, the total generated electricity from steam power plants was reduced by $2.9 \%$ in the same period.

Besides, Table 3 shows the influence of fuel consumption by power plants and the related emission of pollutants; as an example, from 2013 to 2015, the emission rate of $\mathrm{SO}_{2}$ in the steam power plants and emission rate of $\mathrm{NO}_{\mathrm{x}}$ in the gas power plants decreased by $51 \%$ and $34.7 \%$, respectively. Decreasing the emissions rate in Iran power plants during 2013 to 2015 results from new strategy of Iran's power sector that planned to enhance the contribution of natural gas as an alternative fuel. It led to a reduction of heavier fuels burning in the fossil fuel power plants.

One of the main sources of air pollution in southeastern Iran is the electrical power plants' burning of a heavy fraction of crude oil. Thermal power plants in this region (Zahedan, Kenarak, Iran Shahr, and Zarand) generate about $0.83 \%$ of total electricity generation in Iran, while these four power plants burned 7.92 and $25.74 \%$ of the total consumption of fuel oil and diesel at Iran's fossil fuel power plants in 2015. In the near future, Iran's energy policy plan is to supply adequate natural gas to all thermal power plants in the country (Iran Energy Balance, 2015, 2017). This action would make a considerable decline in gas emissions. The new pipeline (Iran Gas Trunkline 7) will provide the transmission of natural gas from the giant South Pars field to Sistan-Baluchestan Province and will join four aforementioned thermal power plants to the natural gas network. Reduction of heavier fuels consumption in power plants and the resultant lower emission of air pollutants would be this strategy's main achievements (Iran Energy Balance, 2015, 2017).

Another approach to decrease the external cost of electricity generation is to increase the capacity of combined cycle plants by transforming the gas power plants to combined cycle and exploitation of new combined cycle power plants until 2023 (Iran Energy Balance, 2015, 2017). Transforming gas power plants to a combined cycle will significantly increase the power plant's thermal efficiency. The average thermal efficiency of gas power plants in 2015 was $30.4 \%$, while it was $45.8 \%$ for combined cycle power plants (Iran Energy Balance, 2015, 2017). Since Iran's power generation system highly depends on fossil fuel resources, any plan to improve the thermal efficiency of a power plant reduces the use of fossil fuels. By having a more energy-efficient power generation system, more fossil fuel resources will be kept, enhancing energy security in the future.

The average old of Iran's thermal power plants is about 30 years (Iran Data Portal, 2018). Employing old power plants leads to a decrease in the safety factor of a power generation system. Consequently, to improve both the safety and efficiency of the power generation system, old power plants need to be substituted with new and energy-efficient power plants such as combined cycle power plants. By executing this strategy, not only will the thermal efficiency of power plants increase, but also the emission of pollutants and the waste of energy will be considerably reduced. According to Iran's Ministry of Energy report, Iran will transform 27 gas power plants into the combined cycle which will add $8270 \mathrm{MW}$ to their generation capacity and will build 24 new combined cycle power plants with $13160 \mathrm{MW}$ total nominate capacities. Also, construction of six gas power plants is planned with $1484 \mathrm{MW}$ capacity (Iran Energy Balance, 2015, 2017). Therefore, the nominal capacity of steam, gas, and combined cycle power plants of Iran will be 15829.2 MW, 10273 MW, and 58004.1 MW, respectively in 2023. 
Table 4. The prediction of power generation and external cost of that in 2023

\begin{tabular}{|c|c|c|c|c|c|c|c|c|c|c|c|}
\hline \multirow[b]{2}{*}{ Year } & \multirow{2}{*}{$\begin{array}{c}\text { Type of } \\
\text { power } \\
\text { plant }\end{array}$} & \multirow{2}{*}{$\begin{array}{c}\text { Power plants } \\
\text { nominal } \\
\text { capacity }(\mathrm{MW})\end{array}$} & \multirow{2}{*}{$\begin{array}{c}\text { Power } \\
\text { generation } \\
\text { (GWh) }\end{array}$} & \multicolumn{5}{|c|}{ Average emission (g/kWh) } & \multicolumn{3}{|c|}{ External cost scenarios (Cents/kWh) } \\
\hline & & & & $\mathbf{P M}_{10}$ & $\mathbf{S O}_{2}$ & $\mathbf{N O}_{\mathbf{x}}$ & $\mathrm{CO}$ & $\mathrm{CO}_{2}$ & Low & Medium & High \\
\hline \multirow{4}{*}{2023} & Steam & 15929.2 & 34437.7 & 0.2 & 4.5 & 2.2 & 1.8 & 745.2 & 0.76 & 1.81 & 8.09 \\
\hline & Gas & 10273 & 28836.2 & 0.1 & 0.5 & 1.8 & 0.1 & 790.5 & 0.36 & 1.04 & 6.82 \\
\hline & C.Cycle & 58004.1 & 316587.2 & 0.1 & 0.2 & 2.9 & 0.1 & 470.0 & 0.26 & 0.71 & 4.25 \\
\hline & Ave. & & & 0.1 & 0.6 & 2.8 & 0.2 & 519.3 & 0.32 & 0.84 & 4.79 \\
\hline
\end{tabular}

Table 5. Trend of export and import of electricity of Iran

\begin{tabular}{ccccccccc}
\hline Year & $\mathbf{2 0 0 8}$ & $\mathbf{2 0 0 9}$ & $\mathbf{2 0 1 0}$ & $\mathbf{2 0 1 1}$ & $\mathbf{2 0 1 2}$ & $\mathbf{2 0 1 3}$ & $\mathbf{2 0 1 4}$ & $\mathbf{2 0 1 5}$ \\
\hline Import $(\mathrm{GWh})$ & 1684.2 & 2068.1 & 3015.4 & 3656.1 & 3897.2 & 3707 & 3771.5 & 4148.2 \\
\hline Export $(\mathrm{GWh})$ & 3875.3 & 6152.4 & 6707 & 8668.2 & 11029.1 & 11585.6 & 9659.9 & 9879.9 \\
\hline
\end{tabular}

New strategy of Iran's energy sector to diminish the environmental effects of power generation leads to a reduction in power generation external cost. As shown in Table 3 and Figure 2, 50\% to $54.5 \%$ reduction of heavy oil and diesel consumption in power plants from 2013 to 2015 was observed. In the same period, increasing contribution of gas and combined cycle power plants in electric supply system (15\% and $15.8 \%$ ) reduced about $34.8 \%, 30.1 \%$, and $19.5 \%$ of the power generation average external cost in low, medium, and high scenarios, respectively.

\section{The Environmental Prospect of Power Generation System}

Power generation capacity increased from 2007 to 2015 with the different annual growth ratio, which varied from 2.25\% to $5.92 \%$ (Iran Energy Balance, 2015, 2017). Based on maximum yearly growth rate, it is predicted that Iran's total power generation in 2023 will be about 397.1 TWh. By assuming the following parameters, the external cost of power generation and the average emissions (per $\mathrm{g} / \mathrm{kWh}$ ) for three fossil fuel power plant types in 2023 is predicted as shown in Table 4. The assumptions are included as follows: a) fuel consumption ratio in three types of power plants in 2023 is similar to 2015; b) Iran's Ministry of Energy projects will be completed as planned; c) average emission of each type of power plants is constant and equal to 2015 values d) constant power generation from other power generation sources such as hydropower, solar, wind, and biomass are equal to 2015, and finally e) the priority of supplying power demand is combined cycle, gas, and steam power plants, respectively.

As indicated in Table 4, by executing Iran's power generation short-term plan, average emissions of $\mathrm{PM}_{10}, \mathrm{SO}_{2}$, $\mathrm{CO}$, and $\mathrm{CO}_{2}$ will be reduced $26.7 \%, 54.2 \%, 65.4 \%$, and $20 \%$, respectively. Also, the external cost of power generation in the low, medium, and high scenarios will be decreased by $28.9 \%$, $27.6 \%$, and $23.1 \%$ respectively.

\section{Iran's Electricity Export}

Iran's electricity network system is connected to all its neighboring countries for the electricity exchange purpose. Iran's power supply system will be able to manage peak power consumption in the country by exchanging electricity. Hence, according to the official energy balance of Iran, under swap deals, Iran exports electricity to Armenia, Azerbaijan, Turkmenistan, and Nakhichevan Autonomous Region in winter and imports it when domestic demand soars in summer (Iran Energy Balance, 2015, 2017). Another goal that encourages Iran to exchange electricity power is the increase in the country's revenue from power exportation. In this case, Iran exports electricity power to Iraq, Turkey, Afghanistan and Pakistan. Trend of export and import of electricity is given in Table 5.

In 2013, 2014, and 2015, Iran exported about 4.36\%, 3.46\%, and $3.49 \%$ of its total electricity generation, respectively (total power generation in these three years are respectively about 262, 274, and $280 \mathrm{TWh}$ ). This amount of exported electricity power is distributed over 12 months of 2013-2015 in different amounts (between $4-11.5 \%$ in a month) as shown in Figure 4. The highest amount of electricity exportation occurred when the power generation system was at the peak of consumption and all types of power plants were generating electricity (May, June, July, August, and September) (Iran Energy Balance, 2015, 2017). This fact shows the important role of fossil fuel power plants in supplying exported electricity power. As a result, the external cost that derives from the emission of the pollutants in power generation should be considered when in planning for sustainable electricity exportation.

Table 3 shows that the highest average of power generation external cost was observed in 2013. Interestingly, the highest exported electricity occurred in the same year. This fact shows the role of heavier fossil fuels in providing electricity for exportation purposes. The latter directly led to inflated emissions, and it imposes more environmental damages. Also, steam power plants due to their ability to consume varied types of fuels in their boilers especially heavy oil fuel, release huge amounts of air pollutants. In summary, steam power plants' external cost is considerably higher than other types of fossil fuel power plants; therefore, the supplement of exported power from this type of plant decreases total revenues of exportation significantly. The exportation price of electricity is calculated using a formula that depends on the oil price, and governments do not disclose it. According to a report issued by the Energy Ministry of Iran, electricity export prices have never undergone such drastic changes, plummeting from 12 cents per kWh to 10 cents in the case of Iran's export to Iraq in 2015 (Ministry of Energy | Iran Data Portal, no date). Hence, the electricity exportation external cost was between $2.1 \%-7.6 \%$ of exportation total income in the low scenario in 2015. This ratio was between $5.9 \%-18.1 \%$ and $35.4 \%-80.1 \%$ in the medium and high scenarios, respectively.

The trend of electricity exportation from 2008 to 2015 showed that Iran tends to increase its exportation capacity. 


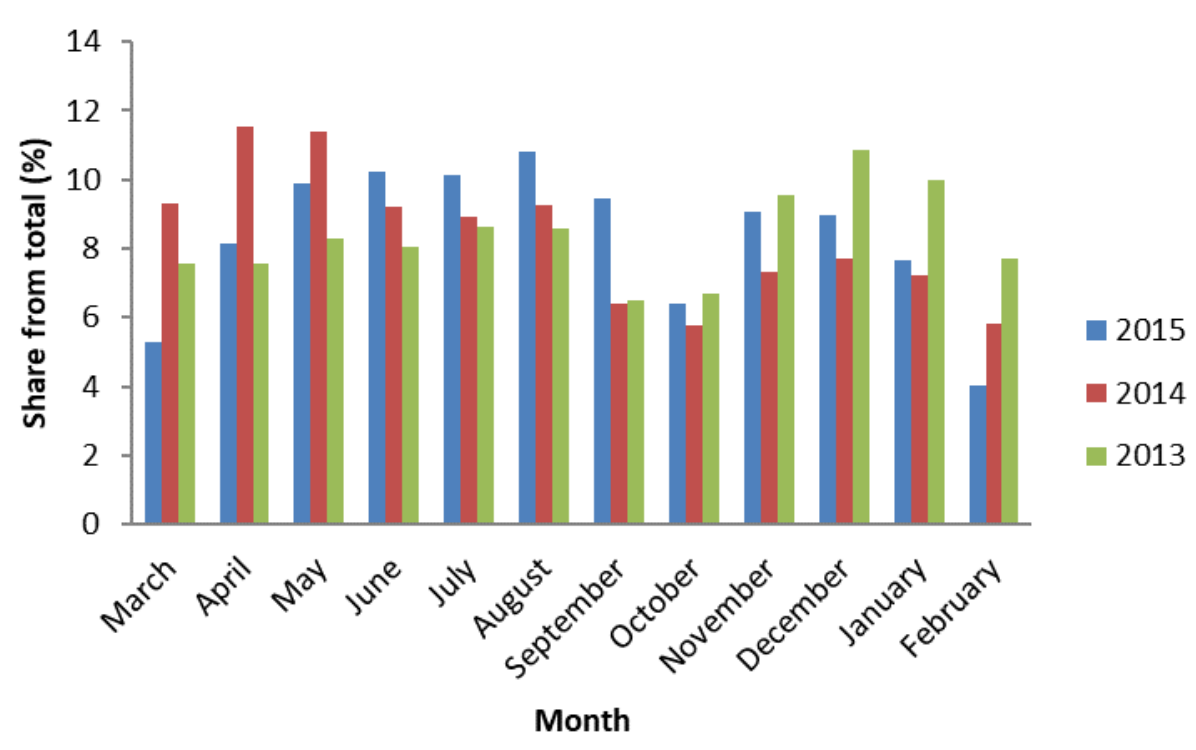

Figure 4. The percentage of exported electricity power per month in 2013-2015

Now, one of the dilemmas for energy sector strategists in Iran is whether it is more lucrative to export electricity or natural gas. It is clear that the incomes obtained from electricity export are more sustainable than those of oil and gas, since the power prices are less dependent on oil and gas prices in the global markets. But concerning the external impact of electricity generation, especially emissions from fossil power plants can make the change in their strategies. Especially in the future, by executing the Paris climate agreement, governments will have to control their greenhouse gas emissions and pay for their extra production. Therefore, power plants' emissions need to be considered seriously.

\section{CONCLUSION}

Most scientists identify the human expansion of the "greenhouse effect" as a result of non-renewable energy generation. Exploring new facilities, applying worldwide strategies, and developing renewable resources could help prevent environmental issues caused by current energy consumption. The external cost of emission such as $\mathrm{CO}_{2}, \mathrm{NO}_{\mathrm{x}}$, $\mathrm{SO}_{2}, \mathrm{CO}$, and $\mathrm{PM}_{10}$ from power generation in Iran was investigated in this study. Iran's power generation system is highly dependent on the fossil fuel power plant. Therefore, it is expected that power generation sector is a source of increasing pollutions and resultant elevated external cost of electricity generation in Iran.

Hence, since 2014, Iran's new energy policy has been implemented to decrease the use of heavy fossil fuels in the power plants and increase the contribution of combined cycle power plants to increase thermal efficiency and reduce the emissions. The average emissions of $\mathrm{PM}_{10}, \mathrm{SO}_{2}, \mathrm{CO}$, and $\mathrm{CO}_{2}$ would reduce by $26.7 \%, 54.2 \%, 65.4 \%$, and $20 \%$, respectively in Iran's new energy policy. Moreover, it is predicted that the average external cost of power generation will decrease by $28.9 \%, 27.6 \%$, and $23.1 \%$ in low, medium, and high scenarios, respectively.
Iran is increasing its electricity exports to the neighboring countries to become the hub of power generation in the region. So, it is helpful to estimate the external cost of electricity exportation, which can range from $2.1 \%-7.6 \%$ of export incomes in the optimistic scenario or from $35.4 \%-80.1 \%$ of export incomes in the pessimistic scenario. Iran's new energy policy not only will help to decrease the environmental impact of power generation but also will increase the power generation capacity, which is ideal for exportation.

Author contributions: All co-authors have involved in all stages of this study while preparing the final version. They all agree with the results and conclusions.

Funding: No external funding is received for this article.

Declaration of interest: The authors declare that they have no competing interests.

Ethics approval and consent to participate: Not applicable.

Availability of data and materials: All data generated or analyzed during this study are available for sharing when appropriate request is directed to corresponding author.

\section{REFERENCES}

Aghahosseini, A., Bogdanov, D., Ghorbani, N. and Breyer, C. (2018). Analysis of $100 \%$ renewable energy for Iran in 2030: integrating solar PV, wind energy and storage. International Journal of Environmental Science and Technology, 15(1), 17-36. https://doi.org/10.1007/s13762017-1373-4

Alavijeh, H. S., Kiyoumarsioskouei, A., Asheri, M. H., Naemi, S., Shahsavari Alavije, H. and Basirat Tabrizia, H. (2013). Greenhouse gas emission measurement and economic analysis of Iran natural gas fired power plants. Energy Policy, 60, 200-207. https://doi.org/10.1016/j.enpol.2013. 05.001

Bank, W. (2004). Islamic Republic of Iran energy-environment review policy note. Washington, DC. 
Bergerson, J. and Lave, L. (2004). Life cycle analysis of power generation systems. In Encyclopedia of Energy (pp. 635645). https://doi.org/10.1016/b0-12-176480-x/00234-5

Bickel, P. and Friendrich, R. (2004). ExternE-externalities of energy-methodology 2005 update.

Bilgin, M. (2009). Geopolitics of European natural gas demand: Supplies from Russia, Caspian and the Middle East. Energy Policy, 37(11), 4482-4492. https://doi.org/10.1016/j.enpol. 2009.05.070

Chatzimouratidis, A. I. and Pilavachi, P. A. (2009). Technological, economic and sustainability evaluation of power plants using the Analytic Hierarchy Process. Energy Policy, 37(3), 778-787. https://doi.org/10.1016/j.enpol. 2008.10.009

Chauhan, A. J., Inskip, H. M., Linaker, C. H., Smith, S., et al. (2003). Personal exposure to nitrogen dioxide (NO2) and the severity of virus-induced asthma in children. Lancet, 361(9373), 1939-1944. https://doi.org/10.1016/S01406736(03)13582-9

Electric Power Industry in Iran (2015-2016) (2015).

Electricity Information 2017 (2017). OECD (Electricity Information). https://doi.org/10.1787/electricity-2017-en

Electricity Information 2019 (2019). OECD (Electricity Information). https://doi.org/10.1787/e0ebb7e9-en

El-Guindy, R. and Mahmoud, M. K. (2014). Environmental externalities from electric power generation: The case of RCREEE member states. International Journal of Thermal \& Environmental Engineering, 7(2), 73-78. https://doi.org/ 10.5383/ijtee.04.02.003

Fouladi Fard, R., Naddafi, K., Yunesian, M., Nabizadeh Nodehi, R., et al. (2016). The assessment of health impacts and external costs of natural gas-fired power plant of Qom. Environmental Science and Pollution Research, 23(20), 20922-20936. https://doi.org/10.1007/s11356-016-7258-0

Gwilliam, K., et al. (2003). Urban air pollution: Policy framework for mobile sources.

Int, C. (2019). Control and treatment of sulfur compounds specially sulfur oxides (SOx) emissions from the petroleum industry: A review. Chemistry International, 2(4), 242-253. https://doi.org/10.31221/osf.io/bxmsr

Iran Data Portal (2018) Ministry of Energy.

Iran Energy Balance, 2015 (2017). Tehran. Available at: https://isn.moe.gov.ir

Iran's Power Industry Analysis Investment Risks \& Opportunities in Post-Sanctions Era (2015). Available at: https://tinyurl.com/ftb32dtr

Kelly, L. and Jordan, J. (2004) The prototype carbon fund addressing challenges of globalization: An independent evaluation of the World Bank's approach to global programs case study.
Mazandarani, A., Mahlia, T. M. I., Chong, W. T., Moghavvemi, M. (2011). Fuel consumption and emission prediction by Iranian power plants until 2025. Renewable and Sustainable Energy Reviews, 1575-1592. https://doi.org/10.1016/j.rser. 2010.11.043

Metz, B., Davidson, O., de Coninck, H., Loos, M. and Meyer, L. (Eds.). (2005). IPCC special report on: Carbon dioxide capture and storage.

Ministry of Energy | Iran Data Portal (no date).

Nazari, S., Shahhoseini, O., Sohrabi-Kashani, A., Davari, S., et al. (2010). Experimental determination and analysis of $\mathrm{CO} 2, \mathrm{SO} 2$ and NOx emission factors in Iran's thermal power plants. Energy, 35(7), 2992-2998. https://doi.org/10.1016/j.energy.2010.03.035

Overview of Greenhouse Gases," Environmental Protection... Google Scholar (2016).

Sabetghadam, M. (2006) Sustainable energy watch summary of report energy and sustainable development in Iran.

Shafie-Pour, M. and Ardestani, M. (2007). Environmental damage costs in Iran by the energy sector. Energy Policy, 35(9), 4413-4423. https://doi.org/10.1016/j.enpol.2007.03. 008

Srinivasan, P. and Shekhar, A. (2020). Internalizing the external cost of gaseous and particulate matter emissions from the coal-based thermal power plants in India. Particulate Science and Technology, 39(5), 632-640. https://doi.org/10.1080/02726351.2020.1815256

Štreimikienè, D. (2020). Externalities of power generation in visegrad countries and their integration through support of renewables. Economics \& Sociology, 14(1), 021. https://doi.org/10.14254/2071

Weinzettel, J., Havránek, M. and Ščasný, M. (2012). A consumption-based indicator of the external costs of electricity. Ecological Indicators, 17, 68-76. https://doi.org/10.1016/j.ecolind.2011.04.035

Widdop, B. (2002). Analysis of carbon monoxide. Annals of Clinical Biochemistry: International Journal of Laboratory Medicine, 39(4), 378-391. https://doi.org/10.1258/ 000456302760042146

Wijaya, M. E. and Limmeechokchai, B. (2010). The hidden costs of fossil power generation in Indonesia: A reduction approach through low carbon society. Songklanakarin Journal of Science and Technology, 32(1), 81-89.

Yin, H., Pizzol, M. and Xu, L. (2017). External costs of PM2.5 pollution in Beijing, China: Uncertainty analysis of multiple health impacts and costs. Environmental Pollution, 226, 356-369. https://doi.org/10.1016/j.envpol.2017.02.029 